\title{
3. Solidarity and health
}

\section{INTRODUCTION}

Can legal rights give substance to the right to health? The previous chapter showed how the predominant interpretation attempts to respond to that question in the affirmative. In this chapter, I will explore the fundaments of a different possibility; namely, the idea that the principle of solidarity can provide an alternative for interpreting this human right in a more consistent way.

I shall take as my starting point the work of Fernando Atria. This scholar argues that the legal relationships emanating from human rights have been framed using the practice of legal rights. ${ }^{1}$ This entails that right holders exercise their claims at the expense of duty bearers. From a historical perspective, Atria points out, the distinctive nature of social rights originates from a republican and socialist vision linked to the principle of solidarity. ${ }^{2}$ Whereas, for those that understand social rights as legal rights, the main or only challenge left consists of ensuring an effective remedy so that social rights can be upgraded to the family of real rights. In that way, all human rights would become integrated, indivisible and protected on an equal footing.

However, accepting arguendo that the principle of solidarity can indeed be applied to clarify social rights, does the structurally adversarial scheme of legal rights assist in this task? Atria's claim is that it does not. Far removed from the notion of solidarity, the emphasis on legal rights individualizes and transforms social rights into property rights. This focus would not just be out of step with the history of social rights, but would also run contrary to solidarity. Justiciability of the right to health, a feature that the predominant interpretation presents with pride, would in fact be problematic. The reason is that the only claims that become justiciable in this framework would be those linked to equality before the law, and those claims do not generate access to

1 Fernando Atria, ‘¿Existen los Derechos Sociales?’ (2004) 4 Discusiones: Derechos Sociales 15 and Fernando Atria, 'Réplica: Derecho y Política a Propósito de los Derechos Sociales' (2004) 4 Discusiones: Derechos Sociales 145.

2 ibid 18. 
the material goods necessary for life - a crucial aspect for the world's majority. In the words of Atria:

[P]ero aun cuando es posible ir más allá de lo que 'queda siempre abierto', y cuando la violación a un derecho social puede ser directamente invocada ante un tribunal, es necesario que ella sea 'reformulada [...] en términos de violación individualizada y concreta, en lugar de en forma genérica'. De este modo el derecho social a la protección de la salud, que originalmente consistía en que se garantizara un nivel de atención de salud a todos (porque una comunidad en la que todos nos preocupamos por los otros es una comunidad más decente que otra en la que cada uno persigue su bienestar individual y el resto lo hace la mano invisible), se convierte en un derecho individual alegado por el demandante de que se obligue al Estado a dar una determinada prestación de salud, sin que las necesidades de los otros puedan ser relevantes (las necesidades de los otros aparecen ante el juez como no distribuidas, es decir, como objetivos de política o aspiraciones comunitarias, y por eso los derechos las triunfan). Lo que llega al tribunal no es un derecho social, no puede ser un derecho social, sino una demanda privada, que expresa ya no la idea de una forma superior de comunidad sino la negación de ésta: la pretensión del demandante de que su interés sea atendido, aun a costa del interés de los demás. ${ }^{3}$

An assumption involved in this account is that solidarity is the notion that most genuinely captures the definition of social rights. This chapter is devoted to the analysis of this assumption. I seek to establish whether solidarity can be demarcated as a distinctive legal principle, in the sense of it being able to provide a conceptual ground that is different to other legal principles. I shall then consider the main accounts of solidarity and explore the way in which these accounts have acquired legal expression. This assumption also entails that the right to health is more aligned to a collective right than to an individual or group right. In order to shed light on the weight of these claims, I will

3 'But even if it is possible to go further from that which "remains always open", and the violation of a social right might be directly invoked before a court, it is still necessary to 'reformulate the claim [...] in terms of an individualized and concrete violation in place of its generic form'. In this way, the social right to the protection of health, which originally consisted in guaranteeing a certain level of healthcare for all (because a community where everybody is concerned about the others is a more decent community than one where each person pursues their own individual welfare and the rest is done by the invisible hand), turns into an individual complaint where the complainant asks that the State should be obliged to give him or her a certain healthcare benefit, while at the same time impeding the needs of others from becoming relevant (the needs of the others appear before the court as non-distributed; that is to say, as political goals or communitarian aspirations, which for the very same reason are triumphed by rights). What comes to court is not a social right, it cannot be a social right, but an actual private claim which no longer expresses the idea of a superior form of community, but its negation: the claim of serving the interest of the complainant even at the expense of the interests of the others' (author's translation). Atria, Existen (n 1) 45. 
proceed as follows. Section two begins by reconstructing the main conceptual accounts of solidarity. Section three looks at the institutional expression of these different concepts. Next, I consider the transition of the narratives on the right to health: from a social and collective idea, to an individual entitlement. I conclude by presenting an analogy with the right to vote where I seek to show that bolder affirmations of equality, such as those I claim solidarity leads to, are already in place in uncontested human rights such as the right to vote. In my view, extending this understanding to social rights is what is actually required to protect both sets of human rights (civil and political vis-à-vis economic, social and cultural) on an equal footing.

\section{A CONCEPTUAL APPROXIMATION}

There are various ways in which to understand solidarity and one important way stems from Roman law. ${ }^{4}$ Napoleon's 1804 Code Civil incorporated the Roman notion of solidarity in the law of obligations. Article 1,200 stipulated:

Il y a solidarité de la part des débiteurs, lorsqu'ils sont obligés à une même chose, de manière que chacun puisse être contraint pour la totalité, et que le paiement fait par un seul libère les autres envers le créancier. ${ }^{5}$

This provision understands solidarity as a form of collective responsibility for certain debts where each and all of the debtors can be held accountable for the totality of the debt by any of the creditors. This definition of solidarity has remained intact in the context of the law of obligations. However, from the time of the French Revolution, and especially from the second half of the nineteenth century, several European authors began to adapt the old Roman meaning of solidarity. Revolutionary France marked the beginning of solidarity's 'rebirth'. This happened, first, through the notion of fraternity or brotherhood. Subsequently, French social thinking by authors such as Pierre Leroux (1789-1871) adapted the term to become a social and political notion. ${ }^{6}$ Amidst the development of capitalism, the idea was to combine individual

\footnotetext{
4 According to Sorto, in solidum obligations are widely registered in the Digest in books IX, X, XIV, XV, XVI, XXVI, XXXIX, XLII, XLIII, XLV, XLVI meaning 'in its entirety' or 'totally', see Fredys Orlando Sorto, 'La Compleja Noción de Solidaridad como Valor y como Derecho: la Conducta de Brasil en Relación a Ciertos Estados Menos Favorecidos' in Mario Losano (ed), Solidaridad y Derechos Humanos en Tiempos de Crisis (Dykinson 2011) 98[1].

5 'There is solidarity on the part of the debtors, when they are obliged to the same thing, so that everyone can be forced for the whole, and the payment made by one only, frees the others towards the creditor' (author's translation).

${ }_{6}$ Stefan Stjernø, Solidarity in Europe: The History of an Idea (CUP 2004) 29.
} 
rights and liberties with social cohesion. ${ }^{7}$ Pierre Leroux proposed a democratic and social constitution based on solidarity; ${ }^{8}$ more specifically, he proposed substituting Christian charity with social solidarity. ${ }^{9}$ The reason was that while charity would have been too vague to lead to concrete legal obligations, the revolutionary notion of fraternity was considered excessively sentimental. ${ }^{10}$

Throughout the nineteenth century, various other doctrines envisioned new ways of understanding society and politics. Saint Simon came up with his model of industrial technocracy. Proudhon proclaimed the abolition of private property. Fourier proposed Phalanstery which, as described by Stjernø, consists of a group of 1,500 to 1,600 people living and working together in harmony in common households. According to Stjernø, solidarity would be applied in four different ways here: first, as a principle of insurance (in the sense of the Code Napoleon); second, as the preparedness to share resources with people in need; third, in describing a feeling of community; and fourth, understood as a guaranteed minimum income and for family support. ${ }^{11}$ It is this fourth meaning which according to Stjernø is closer to the association between solidarity and the modern welfare state. ${ }^{12}$

Another important author was Léon Burgeois (1851-1925). Burgeois developed the work of Auguste Comte who, being against both laissez-faire and communism, had conceived solidarity as continuity: an intergenerational dependence that makes the accumulation of experiences and resources possible, allowing the production of goods and services. Paraphrasing Comte, Stjernø comments that 'because wealth is created by the effort of many, the individual is not free to use his wealth as he pleases. Wealth is always entrusted to someone tacitly for a social purpose'. ${ }^{13}$ Burgeois understood solidarity as a legal obligation: an inter-generational duty in favour of the ancestors and the contemporary. This duty would be justified not in a moral, but in a legal obligation - a quasi-contract. Unlike Rousseau's social contract, Burgeois thought that civil society was founded on a quasi-contract, a will that

ibid 26.

Mario Losano, 'La Cuestión Social y el Solidarismo Francés' in Mario Losano (ed), Solidaridad y Derechos Humanos en Tiempos de Crisis (Dykinson 2011) 17.

Stjernø (n 6) 29.

Losano (n 8) 19.

Stjernø (n 6) 28.

ibid.

Stjernø (n 6) 32. 
could only be presumed. According to Mario Losano, Burgeois' understanding of the obligation of solidarity can be described in the following way:

- Who must pay? Those that have become richer thanks to present or past members of society. The owner of property does not have an absolute right over property.

- Who receives the payment? All those that have not received their share in the goods created by social collaboration. Since these creditors cannot be individualized, the State or societies of beneficence can assume their representation.

- How much to pay? The sum is fixed considering the present circumstances as if society were based on a contract retroactively adopted. Ultimately, a minimum amount is needed to protect against the risks of life.

- How to pay? Voluntarily, in favour of the abovementioned societies of beneficence. If the payment is not carried out, the State intervenes making the social solidarity tax obligatory. Just like with respect for other legal obligations, the State acts as the guarantor of all contracts. ${ }^{14}$

The most famous representative of the French tradition on solidarity is Émile Durkheim (1858-1917). In his The Division of Labour in Society, Durkheim formulated a sharp critique against liberalism. Stjernø comments that contrary to Hobbes, Locke, Spencer and others, Durkheim argued that what held society together was not the result of rational calculation, self-interest or social contract; society would be 'based upon social norms, shared values and rituals, and solidarity is one of the normative mechanisms that integrate members of society'. ${ }^{15}$ In Durkheim's account, deep social inequities would compromise solidarity. ${ }^{16}$

Later, with the emergence of social democracy after World War II, solidarity was reinvigorated. Referring to the idea of solidarity in this period, Stjernø summarizes it as:

$[\mathrm{T}]$ he preparedness to share resources with others by personal contribution to those in struggle or in need and through taxation and redistribution organized by the State. [...] Solidarity implies a readiness for collective action and a will to institutionalize that collective action through the establishment of rights and citizenship. ${ }^{17}$

This account entails a modern way of linking solidarity to concrete operative modes of State action: collection of taxes, and their redistribution through

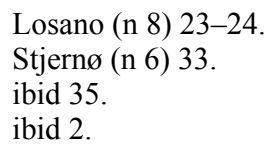


rights and citizenship status. In his seminal essay Citizenship and Social Class ${ }^{18}$ the sociologist TH Marshall linked the three sets of basic rights - civil, political and social - to the citizenship project. To Marshall, the end of the nineteenth century in the UK marked a shift in the notion of social citizenship: from assistance to the destitute - represented by Britain's Poor Laws ${ }^{19}$ - to class restructuring through redistribution, progressive taxation and social policy. Marshall did not regard social citizenship as the improvement of the conditions of those living under extreme poverty, ${ }^{20}$ contemporary notions of citizenship had to go beyond the combatting of destitution, and extend to the struggle against social inequalities. Marshall understood social citizenship as part of a larger project aimed at attaining 'a kind of basic human equality'. ${ }^{21}$ First through civil rights, then by means of political rights, and finally through social rights:

[C]lass-abatement is still the aim of social rights, but it has acquired a new meaning. It is no longer merely an attempt to abate the obvious nuisance of destitution in the lowest ranks of society. It has assumed the guise of action modifying the whole pattern of social inequality. It is no longer content to raise the floor-level in the basement of the social edifice, leaving the superstructure as it was. It has begun to remodel the whole building, and it might even end by converting a sky-scraper into a bungalow. ${ }^{22}$

Stjernø comments in this respect that:

In a modern society there can be no real solidarity, either in a socialist, social democratic or Christian democratic version, if solidarity is not institutionalized. This means that solidarity in modern societies must be embedded in public economic, social and educational policies and in international trade and foreign policy. There can be no solidarity without accepting the right to political participation and expression of opinion, legal rights to protection against the hazards of life and terms of trade, and foreign aid that embodies the aim to share resources and improve the situation of peoples in other parts of the world. In his classic essay, Citizenship and Social Class, TH Marshall directed our attention to how the concept of citizenship expanded from including first, civil rights in the eighteenth century to political rights in the nineteenth century, and finally, social rights in the twentieth century (Marshall 1965). Without using the term solidarity, his emphasis on the concept of citizenship makes clear that the concept of citizenship is a condition for solidarity in modern society. ${ }^{23}$

\footnotetext{
TH Marshall, Citizenship and Social Class and Other Essays (CUP 1950).

TH Marshall, The Right to Welfare and Other Essays (Heinemann 1981) 57.

I take this line of argument from Atria, Existen (n 1) 32-33.

Marshall, Citizenship (n 18) 8.

Marshall, Citizenship (n 18) 47.

Stjernø (n 6) 307.
} 
Contemporary notions of solidarity include the work of philosophers such as Jacques Maritain and Michael Sandel. To the former, solidarity appears closely connected to human rights. According to William Sweet, Maritain would like people to respect human rights and actively engage in work that will promote these rights. In doing so, people would develop the disposition to 'be in solidarity' which is necessary as human rights are a matter of common interest. ${ }^{24}$ To Sandel, solidarity appears to be a requisite for democratic citizenship. Sandel submits that excessive inequalities, in terms of a too great 'gap between rich and poor', will ultimately 'undermine the solidarity that democratic citizenship requires'. Drawing from the reality of the US, Sandel comments:

As inequality deepens, rich and poor live increasingly separate lives. The affluent send their children to private schools (or to public schools in wealthy suburbs), leaving urban public schools to the children of families who have no alternative. A similar trend leads to the secession by the privileged from other public institutions and facilities. Private health clubs replace municipal recreation centers and swimming pools. Upscale residential communities hire private security guards and rely less on public police protection. A second or third car removes the need to rely on public transportation. And so on. The affluent secede from public places and services, leaving them to those who can't afford anything else. This has two bad effects, one fiscal, the other civil. First, public services deteriorate, as those who no longer use those services become less willing to support them with their taxes. Second, public institutions such as schools, parks, playgrounds, and community centers cease to be places where citizens from different walks of life encounter one another. Institutions that once gathered people together and served as informal schools of civic virtue become few and far between. The hollowing out of the public realm makes it difficult to cultivate the solidarity and sense of community on which democratic citizenship depends. ${ }^{25}$

In line with TH Marshall, Sandel's account shows concern towards the rise of economic disparities, but his point is mainly about the value of communities characterized by greater social cohesion. ${ }^{26}$ Have legal institutions developed this concern?

24 William Sweet, 'Solidarity and Human Rights' in William Sweet (ed), Philosophical Theory and the Universal Declaration of Human Rights (University of Ottawa Press 2003) 226-27.

25 Michael Sandel, Justice: What's the Right Thing to Do? (Penguin Books 2009) 266-67.

26 According to a report issued by the Economic Commission for Latin America and the Caribbean (ECLAC), social cohesion includes three components: (1) distances or divides (reflected in employment, incomes and poverty, social welfare, education, access to new technologies, health, consumption and the availability of basic services); (2) institutional inclusion-exclusion mechanisms (they have an effect upon 


\section{AN INSTITUTIONAL APPROXIMATION}

In Austria, Karl Renner (1870-1950) and Anton Menger (1841-1906) formed part of a school of thought known as the Austromarxists. While the former worked on the social function of private law, the latter criticized civil law as being classist. Family law, inheritance law and the law of obligations focused fundamentally on the problems of the richer classes. Menger devised the critical need of focusing on the needs of the poorer families. ${ }^{27}$

In Germany, Marxism had become a dominating influence in the labour movement. According to Stjernø, the concept of solidarity developed later and was adapted to express the need for cohesion and unity in the working class and in the labour movement.$^{28}$ Later, Catholic social thought developed French solidarity, especially after Leo XIII's Rerum Novarum encyclical letter. ${ }^{29}$ Based on these ideas, but also following Soviet models, the Weimar Republic carried out several legislative and institutional innovations. In 1919, a council for the national economy was created. The council served as an advisory body for the government with the power to propose bills for legislative discussion. The council brought together 326 representatives of workers, employers, consumers, public employees and liberal professions. The government appointed 24 of these representatives. When they ascended to power, the Nazis suppressed the council. ${ }^{30}$ Throughout the period of National Socialism the provision of social rights remained strong, but the principle of universality, which applied from the time of Bismarck's social laws, disappeared. The provision was thus restricted to specific groups of the population on the grounds of race..$^{31}$

In the UK, the 'Beveridge Report' largely determined the structure of the country until the 1960s. The project, established in 1942, had to wait until the 1945 election when Clement Atlee defeated Winston Churchill. The National Health Service (NHS), created in 1949 by Aneurin Bevan, was founded on the

the structure of opportunities, accumulation of advantages and disadvantages, and the processes and results of inclusion-exclusion); and (3) sense of belonging (its dimensions are multiculturalism and non-discrimination, social capital (informal social networks, confidence and participation), prosocial values and solidarity, future expectations and prospects of social mobility, and the sense of integration and social affiliation). Economic Commission for Latin America and the Caribbean (ECLAC) and EuropeAid, 'A System of Indicators for Monitoring Social Cohesion in Latin America' (United Nations 2007) < https://www.cepal.org/en/publications/2888-system-indicators -monitoring-social-cohesion-latin-america $>$ accessed 3 February 2021, 27-28.

27 Losano (n 8) 27-28.

28 Stjernø (n 6) 26.

29 Losano (n 8) 32.

30 ibid 34-35.

31 ibid 46. 
basis of three principles: (1) the health system must respond to the needs of all; (2) the provision must be free of charge at the point of delivery; and (3) the provision must be distributed in accordance to need and not ability to pay. ${ }^{32}$ Although the NHS is the most well-known product of the Beveridge Report, Beveridge's ideas went further and contemplated measures to control the labour force, fiscal measures inspired by Keynes and comprehensive control over the means of production. ${ }^{33}$

In Chile, the civic-military coup of 11 September 1973 entailed a major shift in policy. The coup erased the developmentalist trend the country had adopted from the 1930s, and more intensely from the 1950s, following the economic theses of ECLAC. ${ }^{34}$ This period also coincided with the establishment of an increasingly wider scheme of social protection. ${ }^{35}$

In the nineteenth century, healthcare had been largely private and social assistance was a task dependent on the charity of the Catholic Church. ${ }^{36}$ The first presidency of Arturo Alessandri Palma (1920-1924) was the first to address workers' social conditions, otherwise referred to as 'the social question' by encyclical letters such as Pope Leo XIII's Rerum Novarum. ${ }^{37}$ In 1924, the Ministry of Hygiene, Assistance and Social Security and the Workers' Social Security Depository (Caja de Seguro Obrero) were created. The function of the Workers' Social Security Depository was to provide coverage of risks related to illness, age and death. ${ }^{38}$ In 1925, the Chilean Constitution was the first in the world to establish a constitutional right 'to the protection of health' ${ }^{39}$ In 1939, under the presidency of the radical Pedro Aguirre Cerda, a new bill sought to unite several dispersed healthcare services under one unitary healthcare service, similar to the British NHS. ${ }^{40}$ The bill became law

32 Fernando Atria, Derechos Sociales y Educación: Un Nuevo Paradgima de lo Público (Lom 2014) 248.

33 Losano (n 8) 51.

34 Gabriel Salazar and Julio Pinto, Historia Contemporánea de Chile: Estado, Legitimidad, Ciudadanía, vol 1 (Lom 1999) 162[81].

35 Tomas Moulián, Chile Actual: Anatomía de un Mito (3rd edn, Lom 2012).

36 Salazar (n 34) 132.

37 Pope Leo XIII, 'Rerum Novarum: Encyclical of Pope Leo XIII on Capital and Labor' (originally published 1891, Libreria Editrice Vaticana) <http://w2.vatican.va/ content/leo-xiii/en/encyclicals/documents/hf_l-xiii_enc_15051891_rerum-novarum $. h t m l>$ accessed 3 February 2021, paras 20,36, 45.

38 Chile's Ministry of Health, 'Hitos de la Salud Chilena' (Chile's Ministry of Health) <http://web.minsal.cl/hitos-de-la-salud-chilena/> accessed 3 February 2021.

39 Iain Byrne, 'Enforcing the Right to Health: Innovative Lessons From Domestic Courts' in Mary Robinson and Andrew Clapham (eds), Realising the Human Right to Health (3 Rüffer and Rub 2009) 526.

40 Arturo Jirón Vargas, 'Recuerdo Médico del Dr. Salvador Allende Gossens' (2013) 53(3) Cuadernos Médico Sociales Chile 158. 
on 8 August 1952 through the Act of Parliament $\mathrm{N}^{\circ} 10,383$. This act created the 'National Health System' (Servicio Nacional de Salud). Its function was to protect the health of the whole population, and contribute to the promotion and recovery of the health of workers, their spouses and children up to the age of $15 .{ }^{41}$

This process developed further under the presidencies of the Christian democrat Eduardo Frei Montalva (1964-1970) and the socialist Salvador Allende Gossens (1970-1973). Under the presidency of the former, an obligatory insurance scheme to cover accidents at work and professional illnesses was created (Act of Parliament 16,744 of 1968). ${ }^{42}$ At the same time, 59 new hospitals were built which doubled the number of hospital beds. ${ }^{43}$ Inspired by Latin American social medicine, ${ }^{44}$ under the presidency of Allende thousands of young volunteer professionals were sent to the south of the country to teach writing and reading skills, and to provide medical attention to a section of the population that had been previously ignored..$^{45}$ A programme of food supplements was extended to all children in primary schools and to all pregnant women. The programme included a daily half litre of milk per family. ${ }^{46}$ At the same time, primary healthcare centres were established at working class neighbourhoods with at least one healthcare centre for every 40,000 inhabitants. ${ }^{47}$ Medical personnel was increased by $6.6 \%$ with an emphasis on dentists and nurses. All this went hand in hand with an extensive programme of healthcare prevention. ${ }^{48}$ The epidemiological impact of the programmes and campaigns

Chile's Ministry of Health, Hitos (n 38).

42 Act of Parliament 16,744 (1 February 1968) (Chile's National Congress) $<$ https:// www.leychile.cl/Navegar?idNorma $=28650 \&$ buscar $=16744>$ accessed 3 February 2021.

43 Marcelo Muñoz, 'Consideraciones Iniciales en torno al Trabajo de Juan Marconi en Chile: El Abordaje Intracomunitario en Salud Mental' (III Congreso Internacional de Investigación y Práctica Profesional en Psicología, XVIII Jornadas de Investigación, Séptimo Encuentro de Investigadores en Psicología del MERCOSUR, Buenos Aires, 2011) <https://www.aacademica.org/000-052/141> accessed 3 February 2021.

44 Oliva López and Florencia Peña, 'Salud y Sociedad: Aportaciones del Pensamiento Latinoamericano' (2006) 1(3) Medicina Social 82; Carlos Molina, 'El Dr. Salvador Allende Gossens a 100 Años de su Nacimiento: una Deuda Pendiente' (2008) 48(2) Cuadernos Médico Sociales Chile 93, 95-96.

45 Carlos Molina, 'Una Mirada Historiográfica acerca del Desarrollo de la Institucionalidad Sanitaria Chilena: 1889-1989' (Tesis para optar al grado de Magister en Historia con Mención en Historia de Chile, Universidad de Chile 2007).

46 Jirón (n 40).

47 Cecilia Sepúlveda Carvajal, 'Salvador Allende y la Salud Pública a 40 años del Golpe de Estado' (2013) 53(3) Cuadernos Médico Sociales Chile 179.

48 ibid. 
throughout this period have been recorded in all health statistics and indicators of morbidity and mortality. ${ }^{49}$

\section{SOLIDARITY AND THE RIGHT TO HEALTH: FROM CLASSICAL TO CONTEMPORARY UNDERSTANDINGS}

Decommodifying a given good, interest or economic area as an action falling under the scope of collective action, represents a trend in political liberalism. ${ }^{50}$ Though timidly, decommodification - not the extension of justiciability - was one of the mechanisms the liberals of the Post-War era resorted to in order to protect social rights. ${ }^{51}$ This Section refers to the transition from that tradition towards the predominant legal interpretation of the right to health.

The major shocks of the twentieth century: World War I, the Great Depression and World War II, were events from which the great reformers of the time, TH Marshall, William Beveridge and John Maynard Keynes, extracted important lessons. ${ }^{52}$ A great deal of the social policy of these so-called New Liberals consisted of coming to terms with the idea that basic social areas had to make the transition towards non-commodities. ${ }^{53}$ Furthering the solidaristic ideals of the nineteenth century, the goal was to generate a real liberty, an equal liberty or freedom for all. ${ }^{54}$ The new liberalism allowed to understand liberty as something that people have or lack in common and to recognize the conflict of interest between labour and capital. ${ }^{55}$ The constitutional compromises of the Weimar Constitution, ${ }^{56}$ but also the Post-War institutions that were organized in Britain, can be understood as expressions of this.

\footnotetext{
49 Molina, 100 (n 44) 97.

50 Svante Nycander, The History of Western Liberalism (2nd edn Uppsala Universiteit 2016) 247-49.

51 Gøsta Esping-Andersen, The Three Worlds of Welfare Capitalism (Polity Press 1990) 42.

52 Mark Blyth, Austerity: The History of a Dangerous Idea (OUP 2013) 117.

53 Peter Dwyer, Understanding Social Citizenship: Themes and Perspectives for Policy and Practice (2nd edn, The Policy Press and the Social Policy Association 2010) 93; TH Marshall connected liberalism with the tradition of solidarity. The "protection against illness, old age and unemployment and guarantees of certain opportunities were both seen as the necessary rights of civilized life and part of the solidaristic goals of society. Taxation could be used to foster this civil solidarity, connecting the private civil to the public civil interest'. Avital Simhony and David Weinstein (eds), The New Liberalism: Reconciling Liberty and Community (CUP 2001) 213.

54 Simhony (n 53) 87-88.

55 Nycander (n 50) 249.

56 Ignacio Sotelo, El Estado Social: Antecedentes, Origen, Desarrollo y Declive
} (Trotta 2010) 196-201. 
The Cold War appears to have contributed to keeping these efforts high on the list. ${ }^{57}$ The state of compromise that ensued after World War II was largely thanks to the fear of the red spectre: either armed conflict with the USSR, or communist infiltration in Western Europe. ${ }^{58}$ On the whole, the European social welfare state responded to that threat. The principles of universality, ${ }^{59}$ access to social services free of charge, and conditionality on need rather than on ability to pay, were put into practice in institutions such as the British NHS. ${ }^{60}$ This form of provision was extremely successful. Access to healthcare became a right of citizenship ${ }^{61}$ and social protection extended from the 'cradle to the grave'. Likewise, income inequality was significantly reduced. ${ }^{62}$ In the context of the East-West ideological confrontation, this also proved that capitalism could be made compatible with equality of condition policies. This move was not the first one of its kind. Von Bismarck had engaged in a similar approach in the context of the emergence of the German working movement at the end of the nineteenth century. ${ }^{63}$ The ideas and institutions he envisioned had so much success that an entire field of law - social law - was created. ${ }^{64}$ In the field of the right to health, the apex of these ideas was reached in the Alma-Ata Declaration in the context of the WHO's strategy of Health for All. ${ }^{65}$

How did liberalism detract from this path? The answer seems partially theoretical and partially practical. Theoretically, the end of this interpretation is linked to the ideological confrontation that ensued within liberalism itself. On the other hand, from a practical perspective, the fall of the Berlin Wall put an end not just to the Cold War, but it also left the predominant arrangements of Post-War liberalism in disarray. These events have had an impact on the way human rights are understood today.

From a theoretical point of view, one should point out the influence exerted by Friedrich Hayek, who regarded the path taken by the New Liberals to be

57 See, for example, in the area of worker's participation, Astrid Hedin 'Cold war isomorphism: Communist and the West European model of worker participation' (2016) 3(2-3) European Journal of Cultural and Political Sociology 229.

58 Prem Jha, The Twilight of the Nation State: Globalisation, Chaos and War (Pluto Press 2006) 295; Kees van der Pijl, Global Rivalries: From the Cold War to Iraq (Pluto Press 2006) 34.

59 Peter Baldwin, The Politics of Social Solidarity: Class Bases of the European Welfare State 1875-1975 (CUP 1990) 60.

60 Allyson Pollock, NHS plc: The Privatisation of Our Health Care (Verso 2005) 83; Atria, Paradigma (n 32) 248.

${ }_{61}$ Sotelo (n 56) 237.

62 Dany Dorling, Inequality and the 1\%(Verso 2014) 11.

63 Baldwin (n 59) 3.

64 Michael Stolleis, History of Social Law in Germany (Springer 2014) 231-32.

65 See ch 2, n 105. 
an unfaithful expression of liberalism. ${ }^{66}$ Together with other thinkers such as Ludwig von Misses, Hayek claimed that only a minimum State and the guarantee of property were genuine representatives of the liberal tradition. ${ }^{67}$

From a practical point of view, a second set of reasons explains the shift away from the state of compromise and more towards the predominant interpretation of social rights. Devoid of the ideological and military deterrent of the USSR, the capitalist system could fully unleash itself. For reasons that I shall explain in the next chapter, during the Cold War human rights had to remain relegated to a minimum. ${ }^{68}$ While the fall of the Berlin Wall made it clear that capitalism had defeated socialism, it seemed less clear at the time that capitalism was also on the march to defeat Post-War liberalism and social democracy. The reinvention of this latter doctrine by UK Prime Minister Tony Blair, in what Antony Giddens called the Third Way, was in fact a full-scale victory for Margaret Thatcher's political legacy. ${ }^{69}$

While the Thatcher era begins after her victory in the 1979 UK election, this process had already begun some years before amidst the 1973 oil crisis. It was that very year that the state of compromise had begun to crumble. In 1973 , in a civic military coup backed by the US, ${ }^{70}$ the Chilean military led by General Pinochet seized power (1973-1990). In the next two decades, General Pinochet brutally revolutionized the country. A new constitution was adopted in 1980; the organization of the economy radically shifted towards a model of open economy, ${ }^{71}$ and the provision of public services was largely privatized. ${ }^{72}$

66 Rachel Turner, Neo-Liberal Ideology: History, Concepts and Policies (2nd edn, Edinburgh University Press 2011) 124, 149-50.

67 ibid 192.

68 See ch 4, s 2.

69 Something of which the former Prime Minister seems to have been quite well aware. When asked, what had been the greatest achievement of her political career, her answer was: 'New Labour'. This seems to suggest that Thatcher had been politically and ideologically so successful that she was able to force her adversaries to choose between redefining their fundamental views or politically succumb. Conor Burns 'Margaret Thatcher's Greatest Achievement: New Labour' (ConservativeHome, 11 April 2008) <http://conservativehome.blogs.com/centreright/2008/04/making-history .html $>$ accessed 3 February 2021; Andy McSmith, Ben Chu and Richard Garner, 'Margaret Thatcher's Legacy: Spilt Milk, New Labour, and the Big Bang - She Changed Everything' The Independent (London, Monday 8 April 2013) <https://www .independent.co.uk/news/uk/politics/margaret-thatchers-legacy-spilt-milk-new-labour -and-the-big-bang-she-changed-everything-8564541.html> accessed 3 February 2021.

70 Noam Chomsky and Edward Herman, The Washington Connection and Third World Fascisms: The Political Economy of Human Rights, vol I (Pluto Press 2015) 58.

${ }^{71}$ Manuel Gárate, La Revolución Capitalista de Chile (1973-2003) (Ediciones Universidad Alberto Hurtado 2012) 191.

${ }^{72}$ ibid 260, 308-16. 
The historian Gabriel Salazar comments on this last episode in the following terms:

$[\mathrm{O}]$ f greater originality was, no doubt, to have privatized and commercialized public services (healthcare, education and social security) of what used to be the welfare state (Estado Social-Benefactor), and of even substantive parts of the public policies of the old Liberal State of 1925 (especially policies of local development). The 'technical' nature of this second wave of commercialization did not respond so much to the fact that new economic groups were being created, but that on the basis of these services and policies, new processes of accumulation were being installed. These (non-productive) processes of accumulation were stress-free as they did not require to despoil workers, but contributors (through healthcare and social security contributions), and parents (through education fees), all with the poor being instrumentalized under poverty-surmounting policies, and with contributors turning into the passive stakeholders of these businesses. ${ }^{73}$

The views of the New Liberals and social democracy became the expression of something antiquated. The identification of social rights with duties and institutions that granted universal protection shifted. Although Thatcher failed in dismantling the NHS, managerial principles that asserted market superiority promised more efficient outcomes in the organization of those services. ${ }^{74}$ These policies were more successfully introduced under Tony Blair. ${ }^{75}$ Within human rights law, social rights became reinterpreted, not corresponding to the identification of the duties, institutions and principles asserted by the New Liberals, but in line with neoconstitutionalism and transformative constitutionalism, which emptied social rights of their communitarian and transformative potential. ${ }^{76}$ In a Fukuamaist world beyond left and right, it was to be expected that the Limburg Principles would place the social justice project largely in the hands of the courts. Yet, their ability to advance this project remained weak amidst their naturally limited democratic legitimacy. Except for the social determinants ${ }^{77}$ the predominant interpretation of the right to health conceived

73 Salazar (n 34) 110.

74 Janet Newman, Modernising Governance: New Labour, Policy and Society (Sage 2001) 47; Turner, Ideology (n 66) 157-59.

75 Newman, Governance (n 74) 92; Pollock (n 60) 54.

76 Atria, Paradigma (n 32) 35, 47, 53.

77 The social determinants of health were not a product of the predominant interpretation. As General Comment 14 acknowledges, its history is linked to the work of the Third Committee of the UNGA, see UNCESCR, 'General Comment 14 The Right to the Highest Attainable Standard of Health', UN Doc E/C.12/2004/4, 11 May 2000, para 8; Vicente Navarro notes that the study of the social determinants of health is not new but in fact quite old. Given his analysis of the living conditions of the English working class, Navarro places Engels as one of the founders of the scholarship on the social determinants of health. See Vicente Navarro, 'History of the Social Determinants 
this right to be basically an individual legal right. As I will demonstrate in the next chapter, the role of the State shifted from direct provider of an equal and universal public service, to the guarantor of an obligation to protect a minimum provision (not necessarily served by the State) to those excluded by the market. ${ }^{78}$

\section{THE RIGHT TO VOTE: AN ANALOGY}

As discussed in chapter two, despite acknowledging a supposed protection on an equal footing, the predominant interpretation of social rights is generally satisfied with the establishment of minimum rights in these areas. In contrast, TH Marshall's conception of rights as waves of rights (first civil, then political, and ultimately social rights) entails a more coherent interrelation between them. An analysis of the right to vote shows that what is really at stake in this human right already prefigures the important dilemmas social rights are required to overcome.

The modern understanding of the right to vote is based on the idea of the rule of the majority. While the notion may be traced back to the old Greeks, ${ }^{79}$ important accommodations had to occur for liberalism to amalgamate with democracy.$^{80}$ It took a virulent and long-lasting political struggle to lead to the removal of census suffrage and other class and property considerations from the right to vote.$^{81}$ Ridding democracy of race considerations and the power of the capital owners of the nineteenth and twentieth centuries, opened the door to the universality of the franchise. In that sense, our modern understanding of the human right to vote mainly stems from the struggles of social movements such as the European working movement, the feminist movement, the US' civil rights movement and the anti-apartheid movement. Modern electoral systems based on universal suffrage and majority rule would not have been possible without them. The struggle against the attempts of curbing the major-

of Health: Global Histories, Contemporary Debates (Review)' (2009) 83(3) Bulletin of the History of Medicine 620.

78 Dwyer (n 53) 65; Turner, Ideology (n 66) 150.

79 Fundamentally in Athens, especially at the Ecclesia, see Ricardo Chueca Rodríguez, La Regla y el Principio de la Mayoría (Centro de Estudios Constitucionales 1993) 27.

${ }^{80}$ Locke was opposed to it, ibid; John Stuart Mill was reluctant towards it, see Sotelo (n 56) 130-31.

81 Brian Roper, The History of Democracy: A Marxist Interpretation (Pluto Press 2013) 128, 135, 207. 
itarianism of democracy is what keeps what is left of the universality of the human right to vote. ${ }^{82}$

The perspective of the Human Rights Committee corroborates the actuality of this view. ${ }^{83}$ This body does not only accept that the right to vote should be universal, but also that it should be enjoyed equally by all. That is to say: the magnitude or the value of each vote must be the same in terms of outcome. The reason is that the right to vote as a human right would be of little worth if despite everyone being assured of it, the enfranchisement did not acknowledge this universality in equal terms; hence, the principle of 'one person, one vote'. This is in line with the New Liberals' views on social rights. They did not think that the goals of these rights were attained whenever every member of society had some access to the right, but only when such access was equal. To arrive at this point, they simply rebelled against the conception that social class and economic privilege could condition the accessing of welfare ${ }^{84}$ and hence, the developing of universal public services.

82 In Citizens United (Supreme Court of the United States, Citizens (see ch 1, n 4)), the United States Supreme Court broke, in a certain way, with the principle of one person, one vote as asserted in Reynolds v Sims 377 U S 533 (1964). Whereas in that decision the Court considered that legislative apportionment schemes could not have the effect of making one vote less valuable than another, Citizens United, by regarding private wealth in the form of donations to political campaigns as protected under freedom of expression, had the effect of giving wealthy voters a greater ability to influence the political process. This trend in case law was recently confirmed in McCutcheon v Fed Election Comm'n 572 US (2014), where the US Supreme Court struck down as unconstitutional the limits on the amount an individual can donate to parties, federal candidates and political action committees combined. Recently, evidence of financial involvement from foreign companies in federal campaigns has emerged. See Jon Schwarz, 'Foreign Spending on U.S. Elections Threatens National Security, FEC Commissioner Says' The Intercept (Washington 12 September 2016).

83 The General Comment states that 'although the Covenant does not impose any particular electoral system, any system operating in a State party must be compatible with the rights protected by Art. 25 and must guarantee and give effect to the free expression of the will of the electors. The principle of one person, one vote, must apply, and within the framework of each State's electoral system, the vote of one elector should be equal to the vote of another. The drawing of electoral boundaries and the method of allocating votes should not distort the distribution of voters or discriminate against any group and should not exclude or restrict unreasonably the right of citizens to choose their representatives freely'. UNHRC, 'CCPR General Comment 25: Article 25 (Participation in Public Affairs and the Right to Vote) The Right to Participate in Public Affairs, Voting Rights and the Right of Equal Access to Public Service', UN Doc CCPR/C/21/Rev.1/Add.7, 12 July 1996, para 21.

${ }_{84}$ TH Marshall, Welfare (n 19) 92; Ricardo García Manrique, La Libertad de Todos: Una Defensa de los Derechos Sociales (El Viejo Topo 2013) 21. 
In terms of its value, the right to vote required the electoral system to make the 'weight' of the entitlement equal when compared to the entitlement of all others (principle of one person, one vote). Concerning the right to health, the view of the New Liberals was not different: the function of the national healthcare system was to give substance to such fundamental equality of result in access to healthcare. Not via justiciability, but by rejecting the idea that access to healthcare could depend on social class and economic privileges, and by making it free to all at point of delivery.

\section{FINAL REMARKS}

In the West, the original components of the right to health can be traced back to the response to the major shocks of the twentieth century: the Great War, the Great Depression and World War II. Notions such as universality and access that was free of charge on the basis of need are by no means exclusive to the Eastern bloc, but reflect fundamental aspects of the protection afforded to social rights by Post-War liberalism. In Europe, this tradition had an earlier antecedent in the nineteenth century: Von Bismarck's social insurance policies. Institutions in various latitudes gave substance to these duties. This occurred in some Latin American countries, the countries of the Eastern bloc, the Scandinavian countries, and major powers in the West such as the UK. As Franklin Delano Roosevelt's Second Charter of Rights shows, the US was not alien to this influence.

Solidarity gives rise to communitarian bonds that tie individuals to communities. When it comes to social rights, solidarity means universal access on equal terms to the material conditions that make liberty and communal life possible. Under solidarity, social services address not individual, but collective problems. Private dynamics are replaced by public dynamics where the areas covered by social rights are socialized through decommodification. As scarcities are distributed among all members of society more equitably, the risks of the weakest members of society are minimized. Solidarity turns concerns for liberty (or the lack of liberty) into a collective concern ('equal liberty', 'liberty for all' or 'real liberty'). In this way, solidarity limits the principle of competence of the modern liberal State (freedom understood as 'autonomy' or 'non-interference'). As an area informed by solidarity, the legal nature of the exchanges and dynamics of social rights is public - they do not resist their reduction into commodities. 